\title{
mHealth and Perinatal Depression in Low-and Middle-Income Countries: A Scoping Review of the Literature
}

\author{
Aliyah Dosani ${ }^{1,2,3, * \mathbb{C}}$, Harshmeet Arora ${ }^{4}$ and Sahil Mazmudar ${ }^{4}$ \\ 1 School of Nursing and Midwifery, Faculty of Health, Community and Education, Mount Royal University, \\ Calgary, AB T3E 6K6, Canada \\ 2 Department of Community Health Sciences, Cumming School of Medicine, University of Calgary, \\ Calgary, AB T2N 1N4, Canada \\ 3 O'Brien Institute for Public Health, Cumming School of Medicine, University of Calgary, Calgary, \\ AB T2N 1N4, Canada \\ 4 Department of Computer and Electrical Engineering, Faculty of Applied Science, \\ University of British Columbia, Vancouver, BC V6T 1Z4, Canada; harshmeet.arora@alumni.ubc.ca (H.A.); \\ sahil.mazmudar@alumni.ubc.ca (S.M.) \\ * Correspondence: adosani@mtroyal.ca
}

Received: 28 August 2020; Accepted: 19 October 2020; Published: 21 October 2020

\begin{abstract}
Women in low- and middle-income countries have high rates of perinatal depression. As smartphones become increasingly accessible around the world, there is an opportunity to explore innovative mHealth tools for the prevention, screening, and management of perinatal depression. We completed a scoping review of the literature pertaining to the use of mobile phone technologies for perinatal depression in low-and middle-income countries. PubMed CINHAL, and Google Scholar databases were searched, generating 423 results. 12 articles met our inclusion criteria. Two of the 12 articles reviewed mobile phone applications. The remaining 9 articles were study protocols or descriptive/intervention studies. Our results reveal that minimal literature is currently available on the use of mobile health for perinatal depression in low- and middle-income countries. We found four articles that present the results of an intervention that were delivered through mobile phones for the treatment of perinatal depressive symptoms and an additional qualitative study describing the perceptions of mothers receiving cognitive behavioral therapy via telephones. These studies demonstrated that depressive symptoms improved after the interventions. There is potential to improve the quality of mHealth interventions, specifically mobile phone applications for perinatal depressive symptoms and depression, through meaningful collaborative work between healthcare professionals and application developers.
\end{abstract}

Keywords: mhealth; mobile phone health applications; perinatal depression; postpartum depression; antenatal depression; low- and middle-income countries; resource-poor countries

\section{Introduction}

Perinatal depression occurs while a woman is pregnant or within 12 months of delivery [1]. While perinatal depression is common among diverse groups of women in many countries around the world [2-5], women in low- and middle-income countries experience a higher burden of this illness [6]. Recent studies have demonstrated that women in low- and middle-income countries have a perinatal depression rate of up to $48.5 \%$ [7-11]. These figures are alarming as the rates reported in high-income countries are much lower, ranging from $6.5 \%$ to $12.9 \%$ during the perinatal period $[6,12]$. Antenatal depression is a significant population health issue since it could result in potentially harmful 
impacts for the mother such as postpartum depression [13,14], and significant adverse outcomes for the infant including preterm birth [15-18] and delays in cognitive, language, and motor development [19] that could last for years to come [20]. Therefore, it is important to identify effective public health interventions that address perinatal depression in ways that are both accessible and acceptable to the population.

mHealth is a subset of eHealth that uses mobile technologies including advancements in innovative applications to address health priorities [21]. While the use of mHealth has been used to improve health services in a number of diseases for over a decade [22], its use in the area of perinatal depression is relatively new. Limited literature is currently available that describes how mHealth has been used with respect to perinatal depression. For example, in high-income countries, mHealth mobile phone applications have been used by women to self-report psychological well-being during pregnancy [23] and to screen for antenatal depression using either mobile phones [24-26] or an iPad [27]. In addition, mHealth has been tested to deliver various interventions including support for women at risk for depression post-discharge from hospital [26], including health information seeking on postpartum depression [28]. Mobile phones have been used to access self-help tools and emotional support for women with postpartum depression [29], as well as patient decision tools for making treatment choices [26]. mHealth has also been used to deliver counseling therapy via text messages [30], family therapy for young mothers with perinatal depressive symptoms [31], cognitive behavioral therapy for antenatal depression [32] and even to address the mental health concerns of fathers to be [33]. However, it is important to understand how the use of mHealth is developing in low- and middle-income countries where the potential for impact, in terms of improving perinatal outcomes, is high.

There are approximately 5 billion mobile phone subscriptions in the world [21]. Approximately $90 \%$ of the world's population and $80 \%$ of people living in rural areas have access to mobile networks [34]. Adoption of smartphones in emerging markets (e.g., Brazil, India, Kenya, Nigeria) is driven largely by the younger population, where individuals between the ages of $18-34$ comprise $60-80 \%$ of smartphone users [35]. In addition, in many low- and middle-income countries, mobile phone networks have evolved more rapidly than other infrastructure including paved roads and electricity [21]. Many people now have access to higher speeds of data transmission in conjunction with inexpensive and more powerful phones [21]. This improvement in available infrastructure presents an opportunity for mobile health applications to serve a demographic that is technologically able and agile that will form the majority of the population receiving healthcare in the decades to come. Furthermore, as our online interactions increase, such mobile health solutions have an opportunity to explore how individuals receive care remotely. Furthermore, many low-and middle-income countries are population-dense, with underdeveloped health systems, and are therefore more vulnerable to public health dangers such as the COVID-19 pandemic [36]. With the COVID-19 pandemic influencing how people interact in person, innovative mobile health solutions have an opportunity to transform how individuals receive care. The objective of our work was to conduct a scoping review of the literature to determine the availability of literature pertaining to the use of mHealth, specifically mobile phones, and perinatal depression in low- and middle-income countries.

\section{Methods}

We completed a scoping review of the literature to assess the status of available literature regarding mHealth and perinatal depression in low- and middle-income countries. Scoping reviews are exploratory and are used to examine the range and nature of a particular topic [37,38]. Specifically, this mapping exercise is used to determine the position of the literature and the magnitude of the research on a given topic [37]. We used Arksey and O'Malley's [39] framework that outlines 5 stages for conducting a scoping review (Figure 1). Our inclusion criteria included articles that: (1) were published in peer-reviewed journals; (2) described the primary study population as women who were pregnant or had given birth in the past 12 months who reside in countries classified by the World Bank [40] as lowand middle-income countries; and/or pregnant women who were identified as users of mobile phone 
applications; (3) defined perinatal depression or anxiety as the outcome of interest; (4) discussed the use of mobile phones (including apps, text messaging-based interventions, or voice or video connection) for the prevention, screening, or treatment of perinatal depression. Articles were included irrespective of their research design and methodological quality, as prescribed by Valaitis and colleagues [38]. As such, we included study protocols, both quantitative and qualitative publications, and reviews of the literature. Exclusion criteria included non-English-language literature, commentaries, editorials, and theses. We searched PubMed, CINAHL Plus via EBSCOhost, and google scholar (Table 1) in July 2020. Our initial search of these databases generated 423 results. We excluded 374 articles after reviewing the titles and abstracts. From the remaining 49 articles, 37 were excluded as they did not meet the inclusion criteria. We included 12 articles for our analysis. Hand searching of the reference list of the remaining 12 articles produced no additional results. All of the 12 articles were published between 2015-2020.

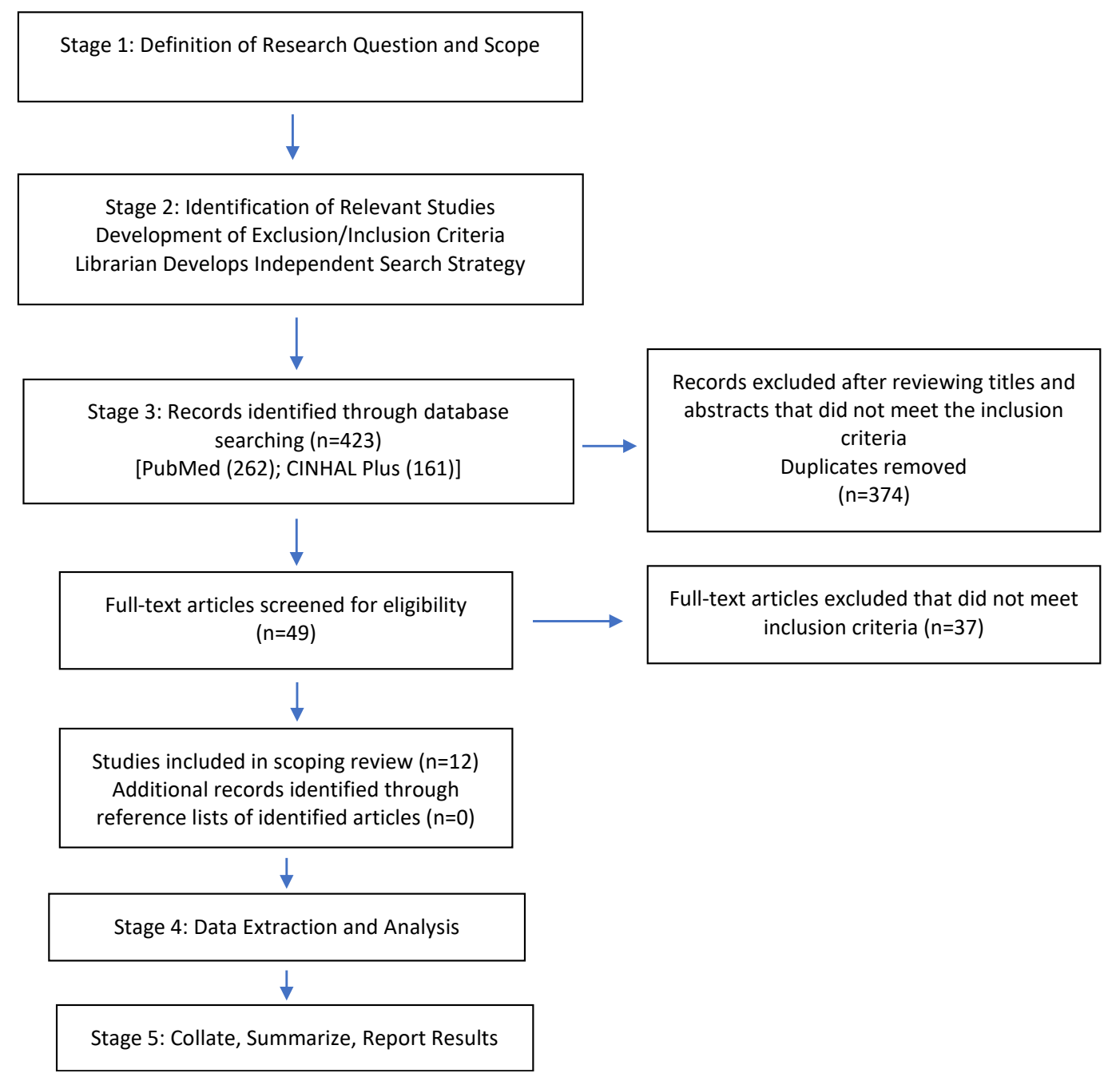

Figure 1. Stages of the scoping literature review. 
Table 1. Search strategy.

\begin{tabular}{|c|c|}
\hline Category & Search Parameters \\
\hline Population & 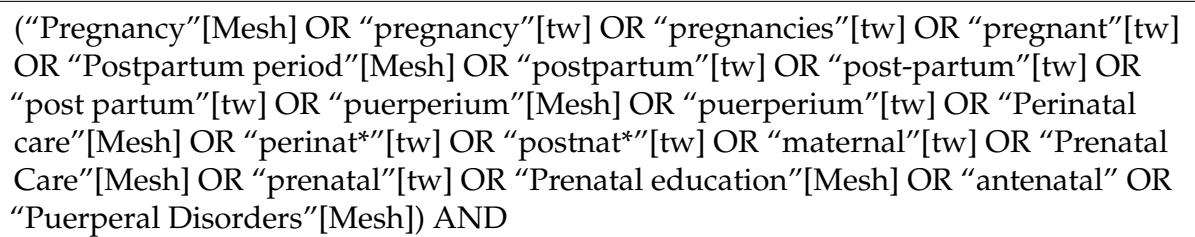 \\
\hline Intervention & 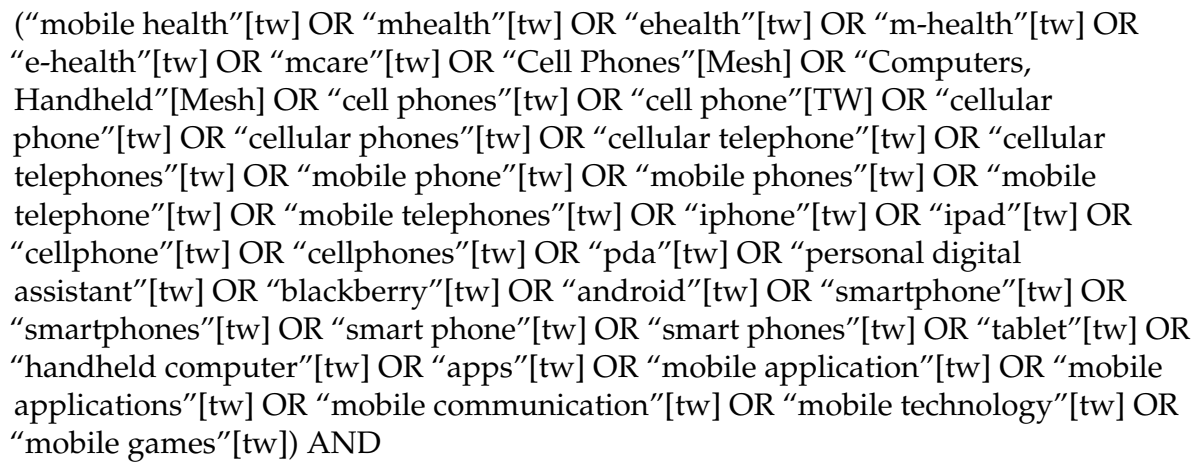 \\
\hline Outcome & $\begin{array}{l}\text { ("depression"[Mesh] OR “depression"[TW] OR “depressed"[TW] OR “depression, } \\
\text { postpartum"[Mesh] OR "mental health"[Mesh] OR "mental health"[TW] OR "Mental } \\
\text { disorders"[Mesh] OR “mental disorder"[TW] OR anxiety[TW] OR “Anxiety } \\
\text { Disorders"[Mesh] OR “Anxiety"[Mesh]) }\end{array}$ \\
\hline
\end{tabular}

\section{Results}

\subsection{Articles Included}

Of the 12 articles we included in our analysis, 3 (25\%) were study protocols [41-43] and 2 $(16.7 \%)$ were reviews of available mobile phone applications related to perinatal depression $[44,45]$. The 7 remaining articles (58.3\%) were research studies [46-52]. These studies were heterogeneous in terms of how mobile phone technology was used (e.g., interactive text messaging, automated text messaging, automated voice mail or use of mobile phone application), the purpose of the use of mobile technology (prevention, screening, and/or treatment), the perinatal timeframe in terms of pregnancy or the postpartum period and population in terms of parity (Tables 2-4). 
Table 2. Data extraction: study design, study population, and details of the intervention.

\begin{tabular}{|c|c|c|c|c|c|}
\hline First Author, Year, Country & Study Design & $\begin{array}{c}\text { Number of Participants } \\
(n-)\end{array}$ & Study Population/Data Collection & $\begin{array}{l}\text { Identification of Depressive Symptoms } \\
\text { and Cut-Off Scores }\end{array}$ & $\begin{array}{l}\text { Depression Assessment } \\
\text { Time Points }\end{array}$ \\
\hline Chan et al., 2019 [46], China & $\begin{array}{l}\text { Single-blind randomized } \\
\text { control trial }\end{array}$ & $\begin{array}{l}n=660 \text { pregnant women } \\
(n \text {-intervention }=330 \text { and } \\
n \text {-control }=330)\end{array}$ & $\begin{array}{l}\text { All first-time expectant mothers. } \\
\text { Less than } 24 \text { weeks of gestation remaining. } \\
\text { Attending the antenatal clinic at a } \\
\text { public hospital }\end{array}$ & $\begin{array}{l}\text { Validated Chinese version of the } \\
\text { Edinburgh Postnatal Depression Scale } \\
\text { (EPDS). No cut-off scores were provided. }\end{array}$ & $\begin{array}{l}\text { First visit to antenatal clinic and } \\
\text { follow-up at } 4 \text { weeks } \\
\text { postpartum }\end{array}$ \\
\hline Green et al., 2019 [41], Kenya & $\begin{array}{l}\text { Single-case experimental } \\
\text { design and qualitative } \\
\text { interviews }\end{array}$ & $\begin{array}{l}\text { Sample size has not been } \\
\text { reported. }\end{array}$ & $\begin{array}{l}\text { At least } 20 \text { weeks' gestation or no more than } \\
6 \text { months postpartum. } \\
\text { Recruited pregnant women and new } \\
\text { mothers from } 2 \text { large public hospitals in } \\
\text { Kiambu County, Kenya that offer SMS } \\
\text { programs that promote healthy motherhood. }\end{array}$ & $\begin{array}{l}\text { Patient Health Questionnaire-9 (PHQ-9), } \\
\text { and a question about mood on a } \\
\text { 10-point scale. }\end{array}$ & $\begin{array}{l}\text { Participants are randomized to } \\
\text { a 1- or 2-week baseline period } \\
\text { and then invited to begin using } \\
\text { Zuri. Participants are prompted } \\
\text { to rate their mood via SMS } \\
\text { every } 3 \text { days during the } \\
\text { baseline and intervention } \\
\text { periods. }\end{array}$ \\
\hline $\begin{array}{l}\text { Gureje et al., } 2015 \text { [42], } \\
\text { Nigeria }\end{array}$ & Randomized control trial & $n=686$ pregnant women & $\begin{array}{l}\text { Pregnant women between the ages of } 16 \text { and } \\
45 \text { years. } \\
\text { Gestational age between } 16 \text { and } 28 \text { weeks. } \\
\text { Conducted in } 29 \text { clinics in Oyo State, Nigeria }\end{array}$ & $\begin{array}{l}\text {-EPDS score } \geq 12 \\
\text {-Confirmed DSM-IV diagnosis of } \\
\text { depression using relevant questions from } \\
\text { the Composite International Diagnostic } \\
\text { Interview }\end{array}$ & $\begin{array}{l}\text { Assessments will be } \\
\text { undertaken at baseline, } 2 \\
\text { months following recruitment } \\
\text { into the study, and } 3,6,9 \text {, and } \\
12 \text { months after childbirth. }\end{array}$ \\
\hline Jannati et al., 2020 [47], Iran & $\begin{array}{l}\text { Non-blinded parallel-group } \\
\text { randomized controlled trial }\end{array}$ & $\begin{array}{l}n=78 \text { new mothers } \\
(n \text {-intervention }=39 \text { and } \\
n \text {-control }=39)\end{array}$ & $\begin{array}{l}\text { Women aged } 18 \text { or above. } \\
\text { Given birth within the last } 6 \text { months. } \\
\text { Attended one of three health care lefts in } \\
\text { Kerman, Iran }\end{array}$ & $\begin{array}{l}\text { EPDS score } \geq 13 \text { Confirmed diagnosis of } \\
\text { postpartum depression within two } \\
\text { weeks after the participants' recruitment } \\
\text { using the International Neuropsychiatric } \\
\text { Interview (MINI) }\end{array}$ & $\begin{array}{l}\text { Assessments were undertaken } \\
\text { at baseline and } 2 \text { months after } \\
\text { baseline. }\end{array}$ \\
\hline Li et al., 2020 [44], China & $\begin{array}{l}\text { Analyzed and evaluated the } \\
\text { contents of all postpartum } \\
\text { depression applications (iOS } \\
\text { and Android) in China }\end{array}$ & $\begin{array}{l}n=19 \text { applications iPhone } \\
(n=6) \text { Android }(n=2) \\
\text { WeChat }(n=11)\end{array}$ & $\begin{array}{l}2 \text { commentators used the PPD -related } \\
\text { keywords to search for three application } \\
\text { platforms in the Chinese market: Android, } \\
\text { iOS, and WeChat, simplified Chinese } \\
\text { and English. }\end{array}$ & Not applicable & Not applicable \\
\hline Mo et al., 2018 [48], China & Cross-sectional study & $n=1304$ pregnant women & $\begin{array}{l}\text { Pregnant women who attended Hunan } \\
\text { Provincial Maternal and Child Health } \\
\text { Hospital. }\end{array}$ & EPDS score $\geq 10$ & $\begin{array}{l}\text { One questionnaire was } \\
\text { completed upon recruitment } \\
\text { into the study }\end{array}$ \\
\hline Ngai et al., 2019 [49], China & $\begin{array}{l}\text { Qualitative study with } \\
\text { semi-structured interviews } \\
\text { analyzed by content analysis. }\end{array}$ & $n=39$ first time mothers & $\begin{array}{l}\text { A sample of } 39 \text { women from } 197 \text { was invited } \\
\text { for semi-structured telephone interviews at } 6 \\
\text { weeks postpartum. }\end{array}$ & EPDS score $\geq 10$ & Not applicable \\
\hline Niksalehi et al., 2018 [50], Iran & $\begin{array}{l}\text { Single-group, pre-test, and } \\
\text { post-test study design. }\end{array}$ & $\begin{array}{l}n=56 \text { postpartum } \\
\text { mothers }\end{array}$ & $\begin{array}{l}\text {-Healthy first-time mothers recruited from a } \\
\text { medical university-affiliated hospital in } \\
\text { Bandar Abbas city, Iran. } \\
\text {-Healthy and live singleton neonates born at } \\
\text { 37-41 weeks of gestation. }\end{array}$ & EPDS score $\geq 12$ & $\begin{array}{l}\text { Data were collected at baseline } \\
\text { ( } 14 \text { days after giving birth) one } \\
\text { week after receiving the } \\
\text { intervention for } 35 \text { days. }\end{array}$ \\
\hline
\end{tabular}


Table 2. Cont.

\begin{tabular}{|c|c|c|c|c|c|}
\hline First Author, Year, Country & Study Design & $\begin{array}{l}\text { Number of Participants } \\
(n-)\end{array}$ & Study Population/Data Collection & $\begin{array}{l}\text { Identification of Depressive Symptoms } \\
\text { and Cut-Off Scores }\end{array}$ & $\begin{array}{l}\text { Depression Assessment } \\
\text { Time Points }\end{array}$ \\
\hline $\begin{array}{l}\text { de Figueiredo et al., } 2015 \text { [51], } \\
\text { Brazil }\end{array}$ & Cross-sectional study & $\begin{array}{l}n=496 \text { pregnant women } \\
(n \text {-coses }=257 \text { and } \\
n \text {-control }=239)\end{array}$ & $\begin{array}{l}\text { Pregnant women from } 25 \text { to } 28 \text { weeks of } \\
\text { gestational age. } \\
\text { Enrolled in prenatal care outpatient. services } \\
\text { in the city of Ribeirão Preto, Brazil. } \\
257 \text { of } 1083 \text { participants ( } 23.7 \%) \text {, had an } \\
\text { EPDS score of } \geq 10 \text {. } \\
\text { All participants were invited to visit the } \\
\text { cinical research unit for a diagnostic } \\
\text { interview with a psychiatrist or psychologist. } \\
\text { After matching by age and date of delivery, } \\
239 \text { women with EPDS scores lower than } 10 \\
\text { were also invited to a face-to-face interview. }\end{array}$ & $\begin{array}{l}\text { Edinburgh Postnatal Depression Scale } \\
\text { (EPDS score } \geq 10 \text { ) }\end{array}$ & $\begin{array}{l}\text { During the first year after } \\
\text { childbirth, the women enrolled } \\
\text { in the original study were } \\
\text { contacted by telephone and } \\
\text { invited to answer the EPDS. } \\
\text { At the time of the diagnostic } \\
\text { interview (SCID), the mothers } \\
\text { completed the EPDS again, but } \\
\text { in a self-administered format. }\end{array}$ \\
\hline $\begin{array}{l}\text { Shamshiri Milani et al., } \\
2015 \text { [52], Iran }\end{array}$ & Randomized control trial & $\begin{array}{l}n=54 \text { postpartum women } \\
(n \text {-intervention }=27 \text { and } \\
n \text {-control }=27)\end{array}$ & $\begin{array}{l}\text { Postpartum women who had term deliveries, } \\
\text { live births were uncomplicated deliveries. } \\
54 \text { eligible mothers out of } 203 \text { postpartum } \\
\text { mothers ( } n=27 \text { per group) who had mild to } \\
\text { moderate depression (>10 to } \\
<14 \text { EPDS Scores). } \\
\text { These cases were recruited and randomly } \\
\text { assigned to the intervention and } \\
\text { control groups. }\end{array}$ & $\begin{array}{l}\text { Edinburgh Postnatal Depression Scale } \\
\text { (EPDS score } \geq 10 \text { ) }\end{array}$ & $\begin{array}{l}10-15 \text { days after childbirth and } \\
6 \text { weeks postpartum }\end{array}$ \\
\hline Sun et al., 2019 [43], China & $\begin{array}{l}\text { Study protocol for a } \\
\text { double-blind randomized } \\
\text { controlled trial }\end{array}$ & $\begin{array}{l}n=120 \text { postpartum } \\
\text { women } \\
(n \text {-intervention }=60 \text { and } \\
n \text {-control }=60)\end{array}$ & $\begin{array}{l}\text { Postpartum women up to } 6 \text { weeks } \\
\text { post-delivery with EPDS score } \geq 9-\leq 12 \text {, } \\
\text { selected randomly from one health left in } \\
\text { each district within Changsha city. }\end{array}$ & $\begin{array}{l}\text { Edinburgh Postnatal Depression Scale } \\
\text { (EPDS score } \geq 9 \text { ) }\end{array}$ & $\begin{array}{l}\text { Baseline }\left(\mathrm{t}_{0}\right) \text {, immediately after } \\
\text { the last intervention }\left(\mathrm{t}_{1}\right), 3 \\
\text { months following the } \\
\text { intervention }\left(\mathrm{t}_{2}\right) \text {, and } 6 \text { months } \\
\text { following the intervention }\left(\mathrm{t}_{3}\right) .\end{array}$ \\
\hline $\begin{array}{l}\text { Zhang et al., } 2017 \text { [45], } \\
\text { Singapore }\end{array}$ & $\begin{array}{l}\text { Evaluation of mobile phone } \\
\text { applications to determine the } \\
\text { quality of information } \\
\text { presented for postnatal } \\
\text { depression. }\end{array}$ & $\begin{array}{l}n=11 \text { android mobile } \\
\text { phone applications } n=3 \\
\text { apple mobile phone } \\
\text { applications }\end{array}$ & $\begin{array}{l}\text { Apple iTunes and Google Android Play store } \\
\text { applications searched. } \\
\text { Inclusion criteria for applications: } \\
\text { "postnatal", "pregnancy", "perinatal", } \\
\text { "depression", "postpartum", and must be } \\
\text { in English. }\end{array}$ & Not applicable & Not applicable \\
\hline
\end{tabular}


Table 3. Data extraction: outcomes.

\begin{tabular}{|c|c|c|c|}
\hline First Author, Year & Intervention and Comparator Group & Primary Outcome Measure & Other Outcome Measures \\
\hline Chan et al., 2019 [46] & $\begin{array}{l}\text { A mobile phone application called iParent, in addition to } \\
\text { in-person nurse-led antenatal classes. } \\
\text { Expectant mothers were able to ask questions that were } \\
\text { answered by obstetricians via private, direct messages } \\
\text { within the application and then shared in the Frequently } \\
\text { Asked Questions module of the application. }\end{array}$ & $\begin{array}{l}\text { The difference in the levels of antenatal and } \\
\text { postnatal depression }\end{array}$ & $\begin{array}{l}\text { Differences between anxiety levels, stress levels, and } \\
\text { health-related quality of life before and after the RCT. } \\
\text { Anxiety and stress levels were assessed with the Anxiety } \\
\text { and Stress subscales of the Depression Anxiety Stress Scale } \\
\text { (DASS). Health-related QoL was measured by the 12-item } \\
\text { Short-Form Health Survey (SF-12). }\end{array}$ \\
\hline Green et al., 2019 [41] & $\begin{array}{l}\text { Automated the Thinking Healthy program via a mobile } \\
\text { phone app called Healthy Moms over } 15 \text { sessions. } \\
\text { During each Healthy Moms session, women will interact } \\
\text { with the automated system via SMS. }\end{array}$ & Depression severity and mood & $\begin{array}{l}\text { Participant engagement with the mobile phone application, } \\
\text { intervention feasibility, and acceptability, variability in } \\
\text { patient response to treatment. }\end{array}$ \\
\hline Gureje et al., 2015 [42] & $\begin{array}{l}\text { Intervention uses the WHO Mental Health Gap Action } \\
\text { Programme Intervention Guide (mhGAP-IG) as adapted for } \\
\text { the health system of Nigeria. } \\
\text { Eight weekly sessions were delivered with case-specific } \\
\text { additional sessions following childbirth. } \\
\text { General physicians and psychiatrists provided mobile } \\
\text { phone supervision, along with automated notifications to } \\
\text { remind mothers of appointments and tasks. }\end{array}$ & $\begin{array}{l}\text { The primary outcome is recovery from } \\
\text { depression }(\text { EPDS }<6 \text { ) at } 6 \text { months }\end{array}$ & $\begin{array}{l}\text { Disability as measured by the WHO and the Disability } \\
\text { Assessment Scale. } \\
\text { Parenting skills using the Maternal Adjustment and } \\
\text { Maternal Attitudes Questionnaire (MAMAs). } \\
\text { Infant Toddler version of the Home Inventory for } \\
\text { Measurement of the Environment. } \\
\text { (HOME-IT) } \\
\text { Maternal attitudes, the experience of stigma by mothers } \\
\text { with the 12-item Discrimination and Stigma Scale. } \\
\text { Health care utilization using The Client Service Receipt } \\
\text { Inventory-PND version. } \\
\text { Infant physical and cognitive development assessed using } \\
\text { Bayley's Scales. }\end{array}$ \\
\hline Jannati et al., 2020 [47] & $\begin{array}{l}\text { Mobile phone-based cognitive-behavioral therapy (CBT) on } \\
\text { postpartum depression called Happy Mom, with eight } \\
\text { weekly lessons. } \\
\text { Lessons are structured as a storybook for mothers to follow } \\
\text { and learn lessons from. } \\
\text { Participants were randomized 1:1 to either the intervention } \\
\text { group (mobile application access) or the control group (no } \\
\text { mobile application access). }\end{array}$ & EPDS score post-intervention & None \\
\hline Li et al., 2020 [44] & $\begin{array}{l}\text { Currently available Chinese mobile phone applications for } \\
\text { postpartum depression. }\end{array}$ & $\begin{array}{l}\text { The adherence of mobile phone applications } \\
\text { with clinical practice-based guidelines. }\end{array}$ & $\begin{array}{l}\text { The Mobile App Rating Scale (MARS) to evaluate } \\
\text { engagement, functionality, aesthetics of the application } \\
\text { features. }\end{array}$ \\
\hline Mo et al., 2018 [48] & No intervention as this was a descriptive study. & $\begin{array}{l}\text { Use of antenatal care mobile phone } \\
\text { applications and antenatal depression. }\end{array}$ & None \\
\hline
\end{tabular}


Table 3. Cont

\begin{tabular}{|c|c|c|c|}
\hline First Author, Year & Intervention and Comparator Group & Primary Outcome Measure & Other Outcome Measures \\
\hline Ngai et al., 2019 [49] & No interventions as this was a qualitative study. & $\begin{array}{l}\text { Specific components of the T-CBT intervention } \\
\text { that women considered helpful in their } \\
\text { preparation for early motherhood. }\end{array}$ & Not applicable \\
\hline Niksalehi et al., 2018 [50] & $\begin{array}{l}\text { Mobile phone SMS support for mothers with postpartum } \\
\text { depression. } \\
\text { Each mother received two daily text messages (morning } \\
\text { and evening) for } 35 \text { days. } \\
\text { Mothers could respond with a message or call the health } \\
\text { care providers in the research team (a nurse and a midwife). }\end{array}$ & Depressive symptoms measured by the EDPS. & $\begin{array}{l}\text { The satisfaction level of participants with the support } \\
\text { received. }\end{array}$ \\
\hline $\begin{array}{l}\text { de Figueiredo et al., } \\
2015 \text { [51] }\end{array}$ & $\begin{array}{l}\text { EPDS administered } \\
\text { by telephone interviews. } \\
\text { Each potential case }(E P D S \geq 10) \text { was invited to a } \\
\text { face-to-face diagnostic interview. } \\
\text { The rest of the participants (EPDS }<10 \text { ) were selected as } \\
\text { controls and matched with potential cases by age and date } \\
\text { of delivery. }\end{array}$ & $\begin{array}{l}\text { The reliability and validity of the EPDS were } \\
\text { administered by telephone interviews. }\end{array}$ & None \\
\hline $\begin{array}{l}\text { Shamshiri Milani et al., } \\
2015 \text { [52] }\end{array}$ & $\begin{array}{l}\text { The intervention group received telephone support } \\
\text { provided by eight healthy volunteers who were trained to } \\
\text { communicate effectively with mothers to manage their } \\
\text { problems. } \\
\text { Each volunteer telephoned } 3 \text { to } 4 \text { mothers at intervals of } 2 \text { to } \\
3 \text { times per week until } 6 \text { weeks after childbirth. }\end{array}$ & EPDS score post-intervention & None \\
\hline Sun et al., 2019 [43] & $\begin{array}{l}\text { Six CBT modules were delivered via mobile phone } \\
\text { application to participants over six weeks. } \\
\text { Each module includes learning content and assignments. } \\
\text { Participants in the control group will also complete six } \\
\text { health education modules using the mobile phone } \\
\text { application which follows the standard of care in the } \\
\text { postpartum period and the child health management. }\end{array}$ & Postpartum depression & $\begin{array}{l}\text { Negative emotion symptoms measured by the depression, } \\
\text { anxiety, and Stress Scale (DASS-21) } \\
\text { Parenting confidence as measured by the Chinese version } \\
\text { of the Parenting Sense of Competence Scale (C-PSOC). }\end{array}$ \\
\hline Zhang et al., 2017 [45] & $\begin{array}{l}\text { Silberg Scale was used in the assessment of the information } \\
\text { quality of smartphone applications. }\end{array}$ & $\begin{array}{l}\text { Information quality score of mobile } \\
\text { applications }\end{array}$ & None \\
\hline
\end{tabular}


Table 4. Data extraction: results and limitations.

\begin{tabular}{|c|c|c|c|}
\hline First Author, Year & Attrition and Adherence & Results (Key Findings) & Limitations \\
\hline Chan et al., 2019 [46] & $\begin{array}{l}\text { At the follow-up T2 survey after the intervention, } \\
\text { the retention rates were } 66.1 \%(\mathrm{n}=218) \text { for the } \\
\text { intervention group and } 68.2 \%(\mathrm{n}=225) \text { for the } \\
\text { control group. }\end{array}$ & $\begin{array}{l}\text { Associations found between: } \\
\text { 1. participation in the intervention and reduced } \\
\text { depression } \\
\text { 2. attendance in TAU classes and increased stress levels }\end{array}$ & $\begin{array}{l}\text { The short postpartum period after which the } \\
\text { follow-up assessment was conducted and the } \\
\text { inclusion of first-time mothers rather than } \\
\text { all mothers. }\end{array}$ \\
\hline Green et al., 2019 [41] & Not applicable & Study protocol—no results were reported. & $\begin{array}{l}\text { Recruited women who live in urban and } \\
\text { peri-urban lefts in one part of Kenya, thus } \\
\text { forgoing generalization of the broader population } \\
\text { of Kenyan women. }\end{array}$ \\
\hline Gureje et al., 2015 [42] & Not applicable & Study protocol - no results were reported. & None reported \\
\hline Jannati et al., 2020 [47] & No information provided & $\begin{array}{l}\text { Before the intervention, there was no statistically } \\
\text { significant difference between the EPDS score between } \\
\text { the two groups }(p>0.001) \text {. } \\
\text { The average EPDS score after intervention was } 8.18 \text { and in } \\
\text { the control group was statistically significant at } 15.05 \text {. }\end{array}$ & $\begin{array}{l}\text { The small sample size necessitates replication. } \\
\text { Some women could have forgotten to study the } \\
\text { sessions provided in the mobile application. } \\
\text { This limitation was addressed by sending SMS } \\
\text { reminders every week. } \\
\text { This research did not obtain information in the } \\
\text { intervention group on the setting, concentration } \\
\text { level, and distractibility. } \\
\text { Evaluation was carried out over two months, and } \\
\text { the long-term effects of this application on the } \\
\text { mood of the mothers need to be investigated. }\end{array}$ \\
\hline Li et al., 2020 [44] & Not applicable & $\begin{array}{l}\text { Postpartum depression applications in China lack known } \\
\text { effective intervention content. } \\
\text { Study suggests that to produce quality mobile apps, } \\
\text { mental health professionals should be involved when } \\
\text { adopting evidence-based guidelines for the prevention of } \\
\text { postpartum depression. }\end{array}$ & $\begin{array}{l}\text { There are no recent guidelines for the prevention } \\
\text { of postpartum depression in China (latest in 2014) } \\
\text { Only determines the existence or absence of } \\
\text { clinical guidelines, rather than the extent of their } \\
\text { effectiveness. } \\
\text { Most applications lacked quality user feedback. }\end{array}$ \\
\hline Mo et al., 2018 [48] & Not applicable & $\begin{array}{l}71.31 \%(930 / 1304) \text { of the pregnant women used mobile } \\
\text { phone applications for antenatal care. } \\
\text { Higher usage of such applications was associated with } \\
\text { urban residency, non-migrant status, first pregnancy, } \\
\text { planned pregnancy, having no previous children, and } \\
\text { wanting to communicate with peer pregnant women. } \\
46.11 \% \text { (601/1304) of pregnant women had depression. } \\
\text { Logistic regression analyses showed that depression was } \\
\text { associated with the availability of disease-screening } \\
\text { functions in the apps (OR 1.78, 95\% CI 1.03-3.06) and } \\
\text { spending } 30 \text { min or more using the app (OR 2.05, } \\
95 \% \text { CI 1.19-3.52). }\end{array}$ & $\begin{array}{l}\text { A cross-sectional study design led to limited data } \\
\text { extrapolation, lacking causal inference. } \\
\text { The demographic questionnaire used in this study } \\
\text { was not tested for reliability and validity. } \\
\text { The authors found heterogeneity in the types of } \\
\text { antenatal care apps used by pregnant women in } \\
\text { their sample. }\end{array}$ \\
\hline
\end{tabular}


Table 4. Cont

\begin{tabular}{|c|c|c|c|}
\hline First Author, Year & Attrition and Adherence & Results (Key Findings) & Limitations \\
\hline Ngai et al., 2019 [49] & None & $\begin{array}{l}\text { Majority of mothers } \\
\text { found T-CBT helpful in increasing confidence in their } \\
\text { maternal role, increased emotional control, and an } \\
\text { increased sense of support. } \\
\text { Facilitators of T-CBT included delivery of the therapy by } \\
\text { a health care professional and the accessibility and } \\
\text { flexibility of T-CBT. } \\
\text { Busy schedule of new mothers and difficulty in meeting } \\
\text { individual learning needs } \\
\text { hindered the effectiveness of T-CBT. } \\
\text { Most mothers would like the T-CBT to be extended over a } \\
\text { longer period of time. }\end{array}$ & $\begin{array}{l}\text { The results of this study may not be generalizable } \\
\text { due to the small sample size. }\end{array}$ \\
\hline Niksalehi et al., 2018 [50] & $\begin{array}{l}56 \text { women were initially enrolled and } \mathrm{n}=2 \text { were } \\
\text { lost } \\
\text { to follow-up. } \\
\mathrm{N}=54 \text { women were included in the analyses. }\end{array}$ & $\begin{array}{l}\text { Mean score of EDPS pre-intervention was } 14.44 \\
(\mathrm{SD}=2.66) \text {. } \\
\text { Mean post-intervention score was } 11.94(\mathrm{SD}=2.49) \text {. } \\
\text { Mean overall decrease in scores on the EPDS pre- and } \\
\text { post-intervention items was } 2.5 \text { points }(p<0.001) . \\
\text { Majority of women }(\mathrm{n}=26[48.1 \%]) \text { were moderately } \\
\text { satisfied with text massages treatment delivery, followed } \\
\text { by low satisfaction }(\mathrm{n}=21[38.9 \%]) \text {, and high satisfaction } \\
(\mathrm{n}=7[13 \%]) \text {. }\end{array}$ & $\begin{array}{l}\text { The single-group and pre-post-study design that } \\
\text { may have resulted in Selection bias resulting in a } \\
\text { homogenous sample that limits the } \\
\text { generalizability of the results. } \\
\text { Researchers used the self-administered EPDS tool } \\
\text { for a postpartum depression diagnosis. }\end{array}$ \\
\hline de Figueiredo et al., 2015 [51] & $\begin{array}{l}161 \text { mothers who had EPDS } \geq 10 \text { withdrew from } \\
\text { the study } \\
161 \text { mothers who had EPDS }<10 \text { withdrew from } \\
\text { the study. Therefore, } n=199 \text { pregnant women } \\
\text { (n-cases }=96 \text { and } n \text {-control }=103 \text { ) were included } \\
\text { in the analyses. }\end{array}$ & $\begin{array}{l}\text { In } 90 \text { participants, the diagnosis of the major depressive } \\
\text { episode was confirmed by the diagnostic interview (EPDS } \\
\geq 10=65 ; \text { EPDS }<10=23 \text { ). } \\
\text { The Cronbach's alpha coefficient was } 0.861 \text {. } \\
\text { The Spearman's correlation between the EPDS } \\
\text { administered by telephone and the self-reported EPDS } \\
\text { was } 0.69(p<0.001) \text {. } \\
\text { The receiver-operating characteristic (ROC) curve for the } \\
\text { EPDS administered by telephone was } 0.78(95 \% \\
\text { confidence interval }(\mathrm{CI})=0.72 \text { to } 0.84) . \\
\text { Scores } \geq 10 \text { showed a sensitivity of } 72.2 \% \text {, a specificity of } \\
71.6 \% \text {, and a positive predictive value of } 67.7 \% \text {. } \\
\text { The application of a telephone interview represents a } \\
\text { method to reduce the underdiagnosis, undertreatment, } \\
\text { and harmful impact of postnatal depression for women, } \\
\text { children, and families. }\end{array}$ & $\begin{array}{l}\text { The large number of subjects who did not attend } \\
\text { the diagnostic assessment }(61.3 \%) \text { despite multiple } \\
\text { attempts to schedule the face-to-face interviews. }\end{array}$ \\
\hline
\end{tabular}


Table 4. Cont.

\begin{tabular}{|c|c|c|c|}
\hline First Author, Year & Attrition and Adherence & Results (Key Findings) & Limitations \\
\hline $\begin{array}{l}\text { Shamshiri Milani et al., } \\
2015 \text { [52] }\end{array}$ & $\begin{array}{l}\text { There were } 5 \text { participants from the intervention } \\
\text { group and } 3 \text { from the control group that were lost } \\
\text { to follow up. Therefore } n=46 \text { women } \\
\text { (n-intervention }=22 \text { and n-control }=24 \text { ) were } \\
\text { included in the analyses. }\end{array}$ & $\begin{array}{l}\text { Mean depression scores before intervention in both } \\
\text { groups were the same. } \\
\text { After intervention, the mean depression scores were } 7.95 \\
\pm 3.45 \text { for the intervention group and } 10.33 \pm 3.93 \text { for the } \\
\text { control group, which was statistically significant } \\
(p=0.035) \text {. } \\
\text { Changes in mean depression scores for both the } \\
\text { intervention }(-4.73 \pm 3.83, p \leq 0.001) \text { and control }(-2.5 \pm \\
3.51, p=0.008) \text { groups were statistically significant. } \\
\text { After the intervention, the mean depression scores in the } \\
\text { intervention group who received telephone support was } \\
\text { significantly lower than the control group. }\end{array}$ & $\begin{array}{l}\text { The study did not include support from family } \\
\text { and husband as an important factor in postpartum } \\
\text { depression. }\end{array}$ \\
\hline Sun et al., 2019 [43] & Not applicable & Study protocol—no results reported. & None reported \\
\hline Zhang et al., 2017 [45] & Not applicable & $\begin{array}{l}14 \text { applications are specifically focused on postnatal } \\
\text { depression and were reviewed. } \\
\text { The average score for the Silberg Scale of these } \\
\text { applications was } 3.0 / 9.0 \text {. } \\
\text { Limited information is available about the creators or } \\
\text { authors of the application, and references for the } \\
\text { information included in the application itself. } \\
\text { There is a need for healthcare professionals and } \\
\text { developers to jointly conceptualize new applications with } \\
\text { better information quality. }\end{array}$ & $\begin{array}{l}\text { Authors identified applications from Apple or the } \\
\text { Android application stores, potentially missing } \\
\text { out on other sources. } \\
\text { The search strategy was limited to applications in } \\
\text { English and did not evaluate the multiple } \\
\text { applications that are available in other languages. } \\
\text { The Silberg Scale has not been validated for the } \\
\text { assessment of information quality for } \\
\text { smartphone applications. } \\
\text { The Silberg Scale does not consider other aspects } \\
\text { that may be relevant for smartphone application } \\
\text { reviews, such as usability and levels } \\
\text { of engagement. }\end{array}$ \\
\hline
\end{tabular}




\subsection{Population and Outcome Measure}

In terms of the population of focus, 2 of the 12 articles (16.7\%) were reviews of mobile phone applications that were intended to be used by women who were pregnant or in the postpartum period [44,45]. Five of the 12 articles (41.7\%), 2 of which were study protocols [41,42,46,48,51], focused on pregnant women. One of these 5 articles $(20 \%)$ included first-time expectant mothers only [46]. The other 5 articles $(41.7 \%)$, including one study protocol, considered postpartum women [43,47-50,52]. Of these 5 articles, $2(40 \%)$ included first time mothers [49,50]. Five of the 12 studies $(41.7 \%)$ took place in China $[43,44,46,48,49]$, followed by 3 studies $(25 \%)$ in Iran $[47,50,52]$. The primary outcome measure of 8 of the 12 studies $(66.7 \%)$ was the depressive symptoms of women who were pregnant or in the postpartum period [ $41-43,46-48,50,52]$. Seven of these articles $[42,43,46-48,50,52]$ described the use of the Edinburgh Postnatal Depression Scale to identify depressive symptoms and one article [41] described the use of the Patient Health Questionnaire-9 to quantify depressive symptoms. One additional study (8.3\%) assessed the validity of the Edinburgh Postnatal Depression Scale when administered via telephone interviews [51].

\subsection{Study Phase and Research Methods}

Of the 12 articles, 3 (25\%) were study protocols where data collection had not yet begun or was in progress [41-43]. Two of the 12 articles were reviews of mobile phone applications. One of these review articles evaluated the contents of all postpartum depression applications in China and their alignment with the guidelines for the prevention and treatment of postpartum depression [44] and the other evaluated mobile phone applications that were available on the Apple iTunes and Google Android play stores [45]. Of the remaining 10 articles, $9(90 \%)$ were quantitative in nature [41-43,46-48,50-52] with 5 articles (55.6\%) using randomized control trials as their research method [42,43,46,47,52]. Two of the 9 articles used cross-sectional study designs [48,51], one article utilized a single-case experimental design [41], and the other article used pre-test and post-test study design [50]. One article was qualitative [49] with another article including a qualitative component [41].

\subsection{Findings}

Four of the 12 articles (33.3\%) described the completion of an intervention and the corresponding results $[46,47,50,52]$. Two of the 4 studies $(50 \%)$ described mothers receiving support in the form of text messages [50] or verbal problem-solving support using mobile phones [52]. One of the four studies $(20 \%)$ delivered cognitive-behavioral therapy modules as their intervention via mobile phone application [47]. The final article $(20 \%)$ provided psychoeducation as the intervention using a mobile phone application [46]. In addition, mothers were able to interact with healthcare professionals using a platform within the application and ask questions related to pregnancy, childbirth, infant health, and care [46]. With respect to results, statistically, significant improvements in the Edinburgh Postnatal Depression scores were observed in all of the 4 studies after the implementation of the interventions described $[46,47,50,52]$.

One of the 12 articles (8.3\%) validated the use of the Edinburgh Postnatal Depression Scale using phone interviews [51]. The diagnosis of a major depressive episode was confirmed by diagnostic interviews with a Cronbach's alpha coefficient of 0.861 . An additional article (8.3\%), found that $71.31 \%$ of their female participants used mobile phone applications for antenatal care with $46.11 \%$ identified as experiencing depressive symptoms [48]. Logistic regression analyses showed that depression was associated with the availability of disease-screening functions in the application and spending $30 \mathrm{~min}$ or more using the application [48]. The one qualitative article (8.3\%) found that cognitive-behavioral therapy delivered via phone to help increase confidence in a maternal role, emotional control, and sense of support [49]. However, while the flexibility of delivery format was helpful given the busy schedules of new mothers, the authors found it difficult to meet the individual learning needs of new mothers [49]. One of the 2 review articles (50.0\%) identified that postpartum depression mobile phone applications 
that are used in China do not include content that is known to be effective in terms of interventions or align with Chinese clinical practice guidelines in the management of postpartum depression [44]. Likewise, the other review article (50\%) found that insufficient information is available regarding the authors or creators of the content in the postpartum depression mobile phone applications or where the information was obtained [45].

\section{Discussion}

This is the first study of its kind, that we are aware of, that reviewed the current state of the literature on mHealth and perinatal depression in low- and middle-income countries. The results of our study indicate that there is minimal literature currently available on the use of mobile health for perinatal depression in low- and middle-income countries. We found four articles that present the results of an intervention that were delivered through mobile phones for the treatment of perinatal depressive symptoms $[46,47,50,52]$ and an additional qualitative study describing the perceptions of mothers receiving cognitive behavioral therapy via telephones [49]. These five studies have shown that both qualitative perceptions of depressive symptoms and quantitative scores of depressive symptoms improved after interventions using mobile phones. While these early studies are promising, more research needs to be conducted with respect to women living in resource-poor settings, particularly in more rural areas, who typically do not have access to specialty perinatal health services that are more easily accessible in urban centers [53]. This work is especially important given that at least half of the world's population cannot access basic health services [54]. The increased use of mobile phones in rural regions of the world [34] can provide an opportunity to leverage technology to improve outcomes for women with depressive symptoms in the perinatal period.

de Figueiredo and colleagues [51] found that screening for perinatal depression using the Edinburgh Postnatal Depression Scale via the telephone to be both reliable and valid in the Brazilian context. Similar work is necessary for other low- and middle-income countries. Other authors have found ways to screen for perinatal depression using mobile phones [24-26]. However, what remains unclear is the reliability and validity of using the Edinburgh Postnatal Depression Scale when self-administered by women through a mobile phone application. Comparable analyses are required for other scales used to screen for perinatal depressive symptoms such as the Patient Health Questionnaire-9. Furthermore, the acceptability of telephone screening versus self-administered questionnaires via mobile phone applications needs to be determined to move research in the area of mHealth and perinatal depression forward in a meaningful way.

mHealth has the potential to become an important service link between the inadequate mental health services available in many parts of the world, particularly resource-poor settings, and the unfulfilled mental healthcare needs of a large number of people worldwide [55]. Our review shows that there are a myriad of mobile phone applications related to perinatal depression that are currently available for women to use in low- and middle-income countries [44,45] and that women in some countries, such as China, are beginning to increasingly use mobile phone applications for perinatal care more generally [48]. However, mobile phone applications currently available lack consistency with respect to the type and quality of information available [44,45]. Improvements in the innovative use of mHealth are critical to addressing perinatal depression in women in many parts of the world. Zhang and colleagues [45] found that current mobile phone applications lacked transparency in terms of both authorship and the evidence-base that framed the components of mobile phone applications, even some lacking references, and information where expected. This lack of transparency indicates a very real and potentially dangerous practice gap between healthcare professionals and application developers [44]. Such disjointed efforts between the knowledge holders, knowledge brokers, and mobile phone application developers ultimately results in unidimensional applications that fail to translate the expertise of healthcare professionals into user-friendly and intuitive mobile applications, and more importantly, those that result in desired outcomes. As such, increased knowledge-sharing efforts 
are required to develop applications that are not only evidence-based but effective in the prevention, screening, and management of perinatal depression.

With access to smart devices growing exponentially, there is a need for open-source projects where the software for the original source code for the mobile phone applications are made freely available and may be redistributed and modified according to the requirement of the user [56]. Open-source projects not only promote a platform for inclusive discussion amongst social innovators, but also allow for pooling resources, and partnerships. Using this open-source approach could also help to avoid barriers to entry due to licensing requirements and intellectual property regulations. Collaboration with open-source coding also has the potential to reduce the cost of designing and implementing the systems, while sharing data and information to improve efficiency and efficacy [56]. In addition, instead of a multitude of potentially unhelpful mobile phone applications being widely available, collaborators in this field could ensure that the applications are evidence-based. Furthermore, while most women who are pregnant or postpartum rely on user evaluations to select a mobile phone application [48], advocating for open-source software could not only improve the quality of applications but ensure that those delivering care can recommend evidence-based mobile phone applications to their clients and patients. Open source eHealth tools have been begun to gain traction in some resource-poor countries [57]. For example, Papadimitriou and colleagues [58] have demonstrated the success of using open source software to screen for mental health concerns in Kashmir. Making perinatal mental health mHealth tools open source would have the potential to increase positive outcomes exponentially.

A limitation of our scoping review of the literature is we chose to exclude articles about the perspectives of those delivering care using mhealth tools. While taking the perspectives of those delivering care, both trained medical professionals and skilled community health workers, is a significant component of understanding the successes and challenges of using mhealth, this was outside of the scope of our work. Studying the perspectives of health care providers or skilled community health workers who are tasked with delivering care is important in moving mhealth initiatives forward and, while related, is nuanced enough to be a separate field of study.

\section{Conclusions}

Minimal literature is currently available on the use of mobile health for perinatal depression in lowand middle-income countries. Research is currently in its early stages with respect to understanding the outcomes of interventions related to perinatal depression delivered via mobile phones. There is an immense amount of opportunity available to build meaningful relationships for health care professionals and mobile phone application developers. Such partnerships can ensure that the work undertaken is transparent and evidence-based to maximize the potential benefits of mHealth.

Author Contributions: Conceptualization, A.D., H.A., and S.M.; methodology, A.D.; data curation, A.D., H.A., and S.M.; writing—original draft preparation, A.D., H.A., and S.M.; writing—review and editing, A.D., H.A. and S.M.; supervision, A.D. All authors have read and agreed to the published version of the manuscript.

Funding: This research received no external funding.

Acknowledgments: We would like to thank Cari Merkley for developing our search strategy.

Conflicts of Interest: The authors declare no conflict of interest.

\section{References}

1. Fisher, J.; Mello, M.C.; Patel, V.; Rahman, A.; Tran, T.; Holton, S.; Holmes, W. Prevalence and determinants of common perinatal mental disorders in women in low-and lower-middle-income countries: A systematic review. Bull. World Health Organ. 2012, 90, 139-149. [CrossRef] [PubMed]

2. Dharma, C.; Lefebvre, D.L.; Lu, Z.; Lou, W.Y.; Becker, A.B.; Mandhane, P.J.; Turvey, S.E.; Moraes, T.J.; Azad, M.B.; Chen, E.; et al. Risk for maternal depressive symptoms and perceived stress by ethnicities in Canada: From pregnancy through the preschool years. Can. J. Psychiatry 2019, 64, 190-198. [CrossRef] [PubMed] 
3. Bauman, B.L.; Ko, J.Y.; Cox, S.; D’Angelo, D.V.; Warner, L.; Folger, S.; Tevendale, H.D.; Coy, K.C.; Harrison, L.; Barfield, W.D. Vital signs: Postpartum depressive symptoms and provider discussions about perinatal depression-United States, 2018. MMWR Morb. Mortal. Wkly. Rep. 2020, 69, 575-581. [CrossRef] [PubMed]

4. Ogbo, F.A.; Eastwood, J.; Hendry, A.; Jalaludin, B.; Agho, K.E.; Barnett, B.; Page, A. Determinants of antenatal depression and postnatal depression in Australia. BMC Psychiatry 2018, 18, 49. [CrossRef]

5. Shakeel, N.; Sletner, L.; Falk, R.S.; Slinning, K.; Martinsen, E.W.; Jenum, A.K.; Eberhard-Gran, M. Prevalence of postpartum depressive symptoms in a multiethnic population and the role of ethnicity and integration. J. Affect. Disord. 2018, 241, 49-58. [CrossRef]

6. Woody, C.A.; Ferrari, A.J.; Siskind, D.J.; Whiteford, H.A.; Harris, M.G. A systematic review and meta-regression of the prevalence and incidence of perinatal depression. J. Affect. Disord. 2017, 219, 86-92. [CrossRef]

7. Patel, H.L.; Ganjiwale, J.D.; Nimbalkar, A.S.; Vani, S.N.; Vasa, R.; Nimbalkar, S.M. Characteristics of postpartum depression in Anand district, Gujarat, India. J. Trop. Pediatr. 2015, 61, 364-369. [CrossRef]

8. Pellowski, J.A.; Bengtson, A.M.; Barnett, W.; DiClemente, K.; Koen, N.; Zar, H.J.; Stein, D.J. Perinatal depression among mothers in a South African birth cohort study: Trajectories from pregnancy to 18 months postpartum. J. Affect. Disord. 2019, 259, 279-287. [CrossRef]

9. Mersha, A.G.; Abebe, S.A.; Sori, L.M.; Abegaz, T.M. Prevalence and associated factors of perinatal depression in Ethiopia: A systematic review and meta-analysis. Depress Res. Treat. 2018, 2018, 8. [CrossRef]

10. Prabhu, S.; George, L.S.; Shyamala, G.; Hebbar, S. Prevalence and associated risk factors of postnatal depression in South Asian region-A systematic review. Indian J. Public Health Res. Dev. 2019, 10, 329-333. [CrossRef]

11. Fellmeth, G.; Plugge, E.; Fazel, M.; Oo, M.M.; Pimanpanarak, M.; Phichitpadungtham, Y.; Wai, K.; Charunwatthana, P.; Simpson, J.A.; Nosten, F.; et al. Prevalence and determinants of perinatal depression among labour migrant and refugee women on the Thai-Myanmar border: A cohort study. BMC Psychiatry 2020, 20, 168. [CrossRef] [PubMed]

12. Gavin, N.I.; Gaynes, B.N.; Lohr, K.N.; Meltzer-Brody, S.; Gartlehner, G.; Swinson, T. Perinatal depression: A systematic review of prevalence and incidence. Obstet Gynecol. 2005, 106, 1071-1083. [CrossRef] [PubMed]

13. Rahman, A. Challenges and opportunities in developing a psychological intervention for perinatal depression in rural Pakistan-A multi-method study. Arch. Womens Ment. Health 2007, 10, 211-219. [CrossRef] [PubMed]

14. Smorti, M.; Ponti, L.; Pancetti, F. A comprehensive analysis of post-partum depression risk factors: The role of socio-demographic, individual, relational, and delivery characteristics. Front. Public Health 2019, 7, 295. [CrossRef] [PubMed]

15. Grote, N.K.; Bridge, J.A.; Gavin, A.R.; Melville, J.L.; Iyengar, S.; Katon, W.J. A meta-analysis of depression during pregnancy and the risk of preterm birth, low birth weight, and intrauterine growth restriction. Arch. Gen Psychiatry 2010, 67, 1012-1024. [CrossRef] [PubMed]

16. Liu, C.; Cnattingius, S.; Bergström, M.; Östberg, V.; Hjern, A. Prenatal parental depression and preterm birth: A national cohort study. Int. J. Obstet. Gynaecol. 2016, 123, 1973-1982. [CrossRef]

17. Li, D.; Liu, L.; Odouli, R. Presence of depressive symptoms during early pregnancy and the risk of preterm delivery: A prospective cohort study. Hum. Reprod. 2009, 24, 146-153. [CrossRef]

18. Fransson, E.; Örtenstrand, A.; Hjelmstedt, A. Antenatal depressive symptoms and preterm birth: A prospective study of a Swedish national sample. Birth 2011, 38, 10-16. [CrossRef]

19. O’Leary, N.; Jairaj, C.; Molloy, E.J.; McAuliffe, F.M.; Nixon, E.; O’Keane, V. Antenatal depression and the impact on infant cognitive, language and motor development at six and twelve months postpartum. Early Hum. Dev. 2019, 134, 41-46. [CrossRef]

20. Weissman, M.M. Postpartum depression and its long-term impact on children: Many new questions. Jama Psychiatry 2018, 75, 227-228. [CrossRef]

21. World Health Organization. mHealth-New Horizons for Health through Mobile Technologies. Global Observatory for eHealth Series Volume 3. Available online: https://www.who.int/goe/publications/goe_mhe alth_web.pdf (accessed on 25 August 2020).

22. Sweileh, W.M.; Al-Jabi, S.W.; AbuTaha, A.S.; Sa'ed, H.Z.; Anayah, F.M.; Sawalha, A.F. Bibliometric analysis of worldwide scientific literature in mobile-health: 2006-2016. BMC Med. Inform. Decis. Mak. 2017, 17, 72. [CrossRef] [PubMed] 
23. Doherty, K.; Barry, M.; Marcano-Belisario, J.; Arnaud, B.; Morrison, C.; Car, J.; Doherty, G. A mobile app for the self-report of psychological well-being during pregnancy (BrightSelf): Qualitative design study. JMIR Ment. Health 2018, 5, e10007. [CrossRef] [PubMed]

24. Dalton, J.A.; Rodger, D.; Wilmore, M.; Humphreys, S.; Skuse, A.; Roberts, C.T.; Clifton, V.L. The Health-e Babies App for antenatal education: Feasibility for socially disadvantaged women. PLoS ONE 2018, 13, e0194337. [CrossRef] [PubMed]

25. Foster, J.; Miller, L.; Isbell, S.; Shields, T.; Worthy, N.; Dunlop, A.L. mHealth to promote pregnancy and interconception health among African-American women at risk for adverse birth outcomes: A pilot study. Mhealth 2015, 1, 20. [PubMed]

26. Gordon, M.; Henderson, R.; Holmes, J.H.; Wolters, M.K.; Bennett, I.M.; SPIRIT (Stress in Pregnancy: Improving Results with Interactive Technology) Group. Participatory design of ehealth solutions for women from vulnerable populations with perinatal depression. J. Am. Med. Inform. Assoc. 2016, 23, 105-109. [CrossRef]

27. Mehralizade, A.; Schor, S.; Coleman, C.M.; Oppenheim, C.E.; Denckla, C.A.; Borba, C.P.; Henderson, D.C.; Wolff, J.; Crane, S.; Nettles-Gomez, P.; et al. Mobile health apps in OB-GYN-embedded psychiatric care: Commentary. JMIR mHealth uHealth 2017, 10, e152. [CrossRef]

28. Guerra-Reyes, L.; Christie, V.M.; Prabhakar, A.; Harris, A.L.; Siek, K.A. Postpartum health information seeking using mobile phones: Experiences of low-income mothers. Matern. Child Health J. 2016, 20, $13-21$. [CrossRef]

29. Baumel, A.; Tinkelman, A.; Mathur, N.; Kane, J.M. Digital peer-support platform (7Cups) as an adjunct treatment for women with postpartum depression: Feasibility, acceptability, and preliminary efficacy study. JMIR mHealth uHealth 2018, 6, e38. [CrossRef]

30. Broom, M.A.; Ladley, A.S.; Rhyne, E.A.; Halloran, D.R. Feasibility and perception of using text messages as an adjunct therapy for low-income, minority mothers with postpartum depression. JMIR Ment. Health 2015, 2, e4. [CrossRef]

31. Cluxton-Keller, F.; Williams, M.; Buteau, J.; Donnelly, C.L.; Stolte, P.; Monroe-Cassel, M.; Bruce, M.L. Video-delivered family therapy for home visited young mothers with perinatal depressive symptoms: Quasi-experimental implementation-effectiveness hybrid trial. JMIR Ment. Health 2018, 5, e11513. [CrossRef]

32. Forsell, E.; Bendix, M.; Holländare, F.; von Schultz, B.S.; Nasiell, J.; Blomdahl-Wetterholm, M.; Eriksson, C.; Kvarned, S.; van der Linden, J.L.; Söderberg, E.; et al. Internet delivered cognitive behavior therapy for antenatal depression: A randomised controlled trial. J. Affect. Disord. 2017, 221, 56-64. [CrossRef] [PubMed]

33. Fletcher, R.; May, C.; Attia, J.; Garfield, C.F.; Skinner, G. Text-based program addressing the mental health of soon-to-be and new fathers (SMS4dads): Protocol for a randomized controlled trial. JMIR Res. Protoc. 2018, 7, e37. [CrossRef] [PubMed]

34. International Telecommunications Union. The World in 2010: ICT Facts and Figures. Available online: http://www.itu.int/ITU-D/ict/material/FactsFigures2010.pdf (accessed on 10 August 2020).

35. Silver, L. Smartphone Ownership is Growing Rapidly around the World, but not Always Equally. Available online: https://www.pewresearch.org/global/2019/02/05/smartphone-ownership-is-growing-rapidly-arou nd-the-world-but-not-always-equally/\#: \{\}:text=Mobile\%20technology\%20has\%20spread\%20rapidly, ac ross\%20nations \%20or\%20within\%20them (accessed on 10 August 2020).

36. United Nations. UN/DESA Policy Brief \#66: COVID-19 and the Least Developed Countries. Available online: https://www.un.org/development/desa/dpad/publication/un-desa-policy-brief-66-covid-19-and-th e-least-developed-countries (accessed on 10 August 2020).

37. Rumrill, P.D.; Fitzgerald, S.M.; Merchant, W.R. Using scoping literature reviews as a means of understanding and interpreting existing literature. Work 2010, 35, 399. [CrossRef]

38. Valaitis, R.; Martin-Misener, R.; Wong, S.T.; MacDonald, M.; Meagher-Stewart, D.; Austin, P.; Kaczorowski, J.; Linda, O.; Savage, R. Methods, strategies and technologies used to conduct a scoping literature review of collaboration between primary care and public health. Prim. Health Care Res. Dev. 2012, 13, 219-236. [CrossRef]

39. Arksey, H.; O'Malley, L. Scoping studies: Towards a methodological framework. Int. J. Soc. Res. Methodol. 2005, 8, 19-32. [CrossRef] 
40. World Bank. World Bank Country and Lending Groups; World Bank: Washington, DC, USA. Available online: https://datahelpdesk.worldbank.org/knowledgebase/articles/906519-world-bank-country-and-le nding-groups (accessed on 10 August 2020).

41. Green, E.P.; Pearson, N.; Rajasekharan, S.; Rauws, M.; Joerin, A.; Kwobah, E.; Musyimi, C.; Bhat, C.; Jones, R.M.; Lai, Y. Expanding access to depression treatment in Kenya through automated psychological support: Protocol for a single-case experimental design pilot study. JMIR Res. Protoc. 2019, 8, e11800. [CrossRef]

42. Gureje, O.; Oladeji, B.D.; Araya, R.; Montgomery, A.A.; Kola, L.; Kirmayer, L.; Zelkowitz, P.; Groleau, D. Expanding care for perinatal women with depression (EXPONATE): Study protocol for a randomized controlled trial of an intervention package for perinatal depression in primary care. BMC Psychiatry 2015, 15, 136. [CrossRef]

43. Sun, M.; Tang, S.; Chen, J.; Li, Y.; Bai, W.; Plummer, V.; Lam, L.; Qin, C.; Cross, W.M. A study protocol of mobile phone app-based cognitive behaviour training for the prevention of postpartum depression among high-risk mothers. BMC Public Health 2019, 19, 710. [CrossRef]

44. Li, Y.; Zhao, Q.; Cross, W.M.; Chen, J.; Qin, C.; Sun, M. Assessing the quality of mobile applications targeting postpartum depression in China. Int. J. Ment. Health Nurs. 2020, 29, 772-785. [CrossRef]

45. Zhang, M.W.; Ho, R.C.; Loh, A.; Wing, T.; Wynne, O.; Chan, S.W.C.; Car, J.; Fung, D.S.S. Current status of postnatal depression smartphone applications available on application stores: An information quality analysis. BMJ Open. 2017, 7, e015655. [CrossRef]

46. Chan, K.L.; Leung, W.C.; Tiwari, A.; Or, K.L.; Ip, P. Using smartphone-based psychoeducation to reduce postnatal depression among first-time mothers: Randomized controlled trial. JMIR mHealth uHealth 2019, 7, e12794. [CrossRef]

47. Jannati, N.; Mazhari, S.; Ahmadian, L.; Mirzaee, M. Effectiveness of an app-based cognitive behavioral therapy program for postpartum depression in primary care: A randomized controlled trial. Int. J. Med. Inform. 2020, 141, 104145. [CrossRef] [PubMed]

48. Mo, Y.; Gong, W.; Wang, J.; Sheng, X.; Xu, D.R. The association between the use of antenatal care smartphone apps in pregnant women and antenatal depression: Cross-sectional study. JMIR mHealth uHealth 2018, 6, e11508. [CrossRef]

49. Ngai, F.W.; Chan, P.S. A qualitative evaluation of telephone-based cognitive-behavioral therapy for postpartum mothers. Clin. Nurs. Res. 2019, 28, 852-868. [CrossRef] [PubMed]

50. Niksalehi, S.; Taghadosi, M.; Mazhariazad, F.; Tashk, M. The effectiveness of mobile phone text massaging support for mothers with postpartum depression: A clinical before and after study. J. Fam. Med. Prim. Care 2018, 7, 1058.

51. De Figueiredo, F.P.; Parada, A.P.; Cardoso, V.C.; Batista, R.F.L.; da Silva, A.A.M.; Barbieri, M.A.; de Carvalho Cavalli, R.; Bettiol, H.; Del-Ben, C.M. Postpartum depression screening by telephone: A good alternative for public health and research. Arch. Womens Ment. Health 2015, 18, 547-553. [CrossRef]

52. Shamshiri Milani, H.; Azargashb, E.; Beyraghi, N.; Defaie, S.; Asbaghi, T. Effect of telephone-based support on postpartum depression: A randomized controlled trial. Int. J. Fertil. Steril. 2015, 9, 247-253.

53. Hussain-Shamsy, N.; Shah, A.; Vigod, S.N.; Zaheer, J.; Seto, E. Mobile health for perinatal depression and anxiety: Scoping review. J. Med. Internet Res. 2020, 22, e17011. [CrossRef]

54. World Bank; WHO. Half the World Lacks Access to Essential Health Services. Available online: https://www.who.int/news-room/detail/13-12-2017-world-bank-and-who-half-the-world-lacks-access-t o-essential-health-services-100-million-still-pushed-into-extreme-poverty-because-of-health-expenses (accessed on 22 August 2020).

55. Sood, M.; Chadda, R.K.; Singh, P. Mobile health (mHealth) in mental health: Scope and applications in low-resource settings. Natl. Med. J. India 2016, 29, 341.

56. Kanter, A.S.; Borland, R.; Barasa, M.; Iiams-Hauser, C.; Velez, O.; Kaonga, N.N.; Berg, M. The importance of using open source technologies and common standards for interoperability within eHealth: Perspectives from the Millennium Villages Project. Adv. Health Care Manag. 2012, 12, 189-204.

57. O'Connor, Y.; O'Sullivan, T.; Gallagher, J.; Heavin, C.; O'Donoghue, J. Developing eXtensible mHealth solutions for low resource settings. In Mining Intelligence and Knowledge Exploration; Springer: Cham, Switzerland, 2014; pp. 361-371. 
58. Papadimitriou, N.; Housen, T.; Ara, S. Use of Mobile Technologies in Data Collection for a Mental Health Survey in Kashmir, India: A Pilot Study; Medecins Sans Frontieres: New Delhi, India, 2015. Available online: https://doi.org/10.7490/f1000research.1000094.1 (accessed on 25 August 2020).

Publisher's Note: MDPI stays neutral with regard to jurisdictional claims in published maps and institutional affiliations.

(C) 2020 by the authors. Licensee MDPI, Basel, Switzerland. This article is an open access article distributed under the terms and conditions of the Creative Commons Attribution (CC BY) license (http://creativecommons.org/licenses/by/4.0/). 